\title{
Healing Process of Dog Teeth after Post Space Preparation and Exposition of the Filling Material to the Oral Environment
}

\author{
Henrian Gonzaga BARBOSA \\ Roberto HOLLAND \\ Valdir de SOUZA \\ Eloi DEZAN JÚNIOR \\ Pedro Felício Estrada BERNABÉ \\ José Arlindo OTOBONI FILHO \\ Mauro Juvenal NERY \\ Discipline of Endodontics, Faculty of Dentistry of Araçatuba, UNESP, Araçatuba, SP, Brazil
}

\begin{abstract}
The purpose of this study was to observe the influence of coronal leakage on the behavior of periapical tissues after root canal filling and post space preparation. Forty root canals of dogs' teeth were instrumented and filled by the lateral condensation technique with gutta percha points and the cements Sealer 26 and Roth. After post space preparation, the remaining filling material was either protected or not protected with a plug of the temporary cement Lumicon. After root canal exposition to the oral environment for 90 days, the animals were killed and specimens were removed and prepared for histomorphological analysis. The Brown and Brenn technique showed $70 \%$ of cases with microorganism leakage for Roth cement, and $20 \%$ with Sealer 26 . When a plug of Lumicon was employed, there was $30 \%$ leakage for Roth cement and $0 \%$ for Sealer 26 . A chronic inflammatory reaction was more frequently observed with Roth cement than with Sealer 26. It was concluded that a plug of Lumicon was efficient in controlling microorganism coronal leakage ( $\mathrm{p}=0.05)$, and that Sealer 26 was more biocompatible and sealed root canals better than Roth sealer $(\mathrm{p}=0.01)$.
\end{abstract}

Key Words: coronal leakage, post space preparation, Lumicon, Roth cement, Sealer 26.

\section{INTRODUCTION}

Many factors have been reported to play a role in root canal treatment failure. If apical microleakage is indeed a cause of root canal treatment failure, loss of coronal seal should also be considered an adverse factor (1). When the coronal portion of the root canal filling is exposed to oral flora, it may allow the contact of bacteria with the periapical tissues (2). Coronal leakage after post space preparation may be more significant because there is less root canal filling material remaining. Gish et al. (3) demonstrated that Streptococcus anginosus could pass through a $5 \mathrm{~mm}$ length of the filled portion of the canal in 72 days after post space preparation. Barrieshi et al. (1), employing a mixed culture of strict anaerobes, observed bacterial penetra- tion through $5 \mathrm{~mm}$ of remaining filling material in an average time of 66 days. Alves et al. (4) studied coronal leakage of microorganisms and bacterial endotoxin after post space preparation. They reported that the average time for total penetration of endotoxin was 23 days and for microorganisms, 62 days.

The reported in vitro observations are very important for the analysis of this problem. Nevertheless, in vivo studies are also necessary because they better simulate what could occur in periapical tissues since many factors present in the oral environment can influence leakage.

The purpose of this experiment was to study, in dogs' teeth, the influence of the type of sealer and of a plug protection on the healing process after post space preparation and exposition of the root canal filling material to the oral environment. 


\section{MATERIAL AND METHODS}

Forty root canals of two 1-year-old mongrel dogs were used in this study. Under general anesthesia with sodium pentobarbital injected intravenously and with the rubber dam in place, the pulp chamber of each tooth was opened. The pulp was removed with barbed broaches, approximately $1 \mathrm{~mm}$ short of the radiographic apex, and the canals were instrumented according the method described by Holland et al. (5). After the use of Gates-Glidden burs \#3, 2, and 1, the canals were instrumented $1 \mathrm{~mm}$ short of the apex up to Kerr file \#40. Step-back instrumentation was done up to Hedstroen file \#80. During the biomechanical preparation, the root canals were thoroughly irrigated with lime water.

The canals were dried with paper points and filled by the lateral condensation technique with guttapercha points and the sealers Roth cement (type 801 Elite; Roth Int., Chicago, IL, USA) and Sealer 26 (Dentsply, Petrópolis, Brazil), a calcium hydroxide cement. Immediately after root filling, a post space was prepared, leaving $5 \mathrm{~mm}$ of the filling material for the groups without a cement plug. In the teeth with a cement plug, the remaining filling material was of 4 $\mathrm{mm}$. In these last teeth a plug of $1 \mathrm{~mm}$ of Lumicon cement (Bayer Dental, Joinville, Brazil) was adapted over the remaining filling. Thus, 4 experimental groups, each with 10 roots, were obtained: I - root canals filled with Sealer 26 and post space preparation; II - root canals filled with Roth sealer and post space preparation; III - root canals filled with Sealer 26 and with a plug of Lumicon after post space preparation; IV - root canals filled with Roth cement and with a plug of

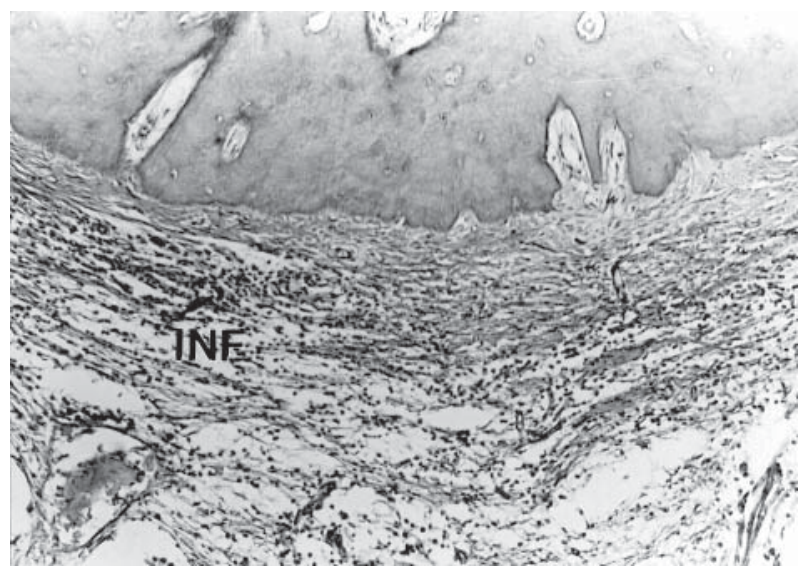

Figure 1. Roth cement: There was a chronic inflammatory reaction (INF) in the periodontal space. (H\&E, 100X).
Lumicon after post space preparation. All 40 root canals remained with the coronal openings exposed to the oral environment for 90 days.

The animals were subsequently killed by administration of an overdose of anesthetic. The specimens were fixed in $10 \%$ neutral-buffered formalin solution and decalcified in formic acid-sodium citrate. Segments of the jaws, each containing one root, were prepared for histological examination in the usual manner. The specimens were embedded in paraffin, serially sectioned to an average thickness of $6 \mu \mathrm{m}$ and stained with hematoxylin and eosin and the Brown and Brenn technique.

Details were recorded concerning neoformed cementum (thickness, extension, biological closure of the canals), cementum resorption, bone tissue resorption, inflammatory reaction (chronic or acute, number of cells and extension of the reaction), periodontal ligament (thickness and organization), root canal filling limit, presence of debris, giant cells and microorganisms. These histomorphological findings were evaluated by scores of 1 to 4,1 being the best result and 4 the worst. The obtained data were submitted to statistical analysis (Kruskal-Wallis and Fisher tests).

\section{RESULTS}

\section{Roth Cement}

When the cement was in contact with the pulp stump there was a layer of necrotic tissue or a chronic inflammatory reaction extending to the periodontal

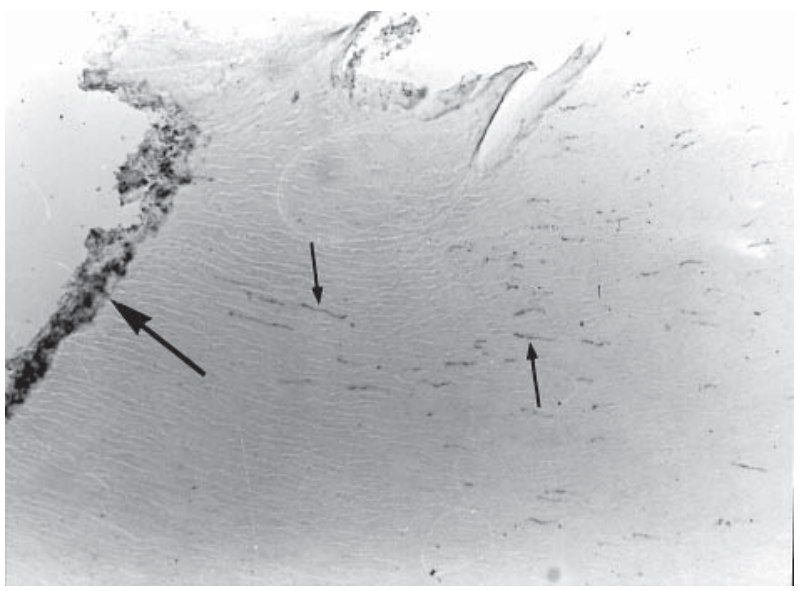

Figure 2. Roth cement: There were Gram-positive microorganisms (arrows) on the surface of the root canal wall and into dental tubules (Brown and Brenn, 200X). 
space, with the presence of lymphocytes, plasmacytes, macrophages and some giant cells. Neoformed eosinophilic cementum, with an average thickness of $20 \mu \mathrm{m}$, was observed in 6 cases, covering the apical cementum or repairing some areas of resorption. No case of complete biological closure was observed.

The periodontal ligament exhibited an average thickness of $441 \mu \mathrm{m}$ and was partially organized, with fibers parallel to the root surface in some cases. In all but one case the periodontal space exhibited a mild to severe chronic inflammatory reaction of various extension, with the presence of lymphocytes, plasmacytes and macrophages (Figure 1). In 4 cases, there were neutrophils but only into the apical delta. Bone tissue exhibited active and inactive resorption areas.

The Brown and Brenn technique showed Grampositive cocci in 7 cases. These microorganisms were localized between the filling material and the dentin wall, into the dentinal tubules, and in some ramifications of the apical delta (Figure 2).

\section{Roth Cement with a Lumicon Plug}

The pulp stumps were partial or totally necrosed or with a chronic inflammatory reaction with lymphocytes, plasmacytes, macrophages and giant cells. Eosinophilic neoformed cementum, with an average thickness of $19 \mu \mathrm{m}$, was observed in 6 cases covering the apical cementum. Complete biological closure was not observed. In the majority of the cases, bone tissue exhibited inactive areas of resorption and in 2 cases some active areas. The periodontal ligament with an average thickness of $436 \mu \mathrm{m}$ was well organized in 2

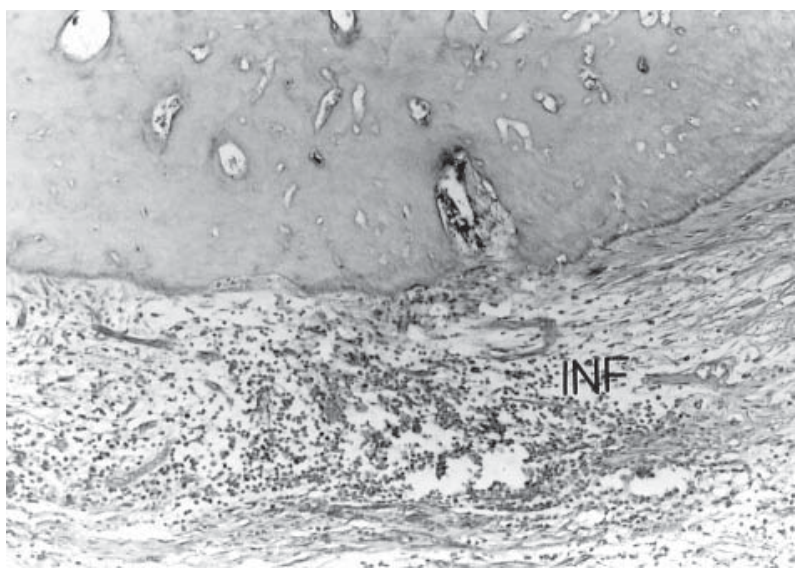

Figure 3. Roth-Lumicon: Note a chronic inflammatory reaction (INF) in the periodontal space (H\&E, 100X). cases and partially or totally disorganized in the remainder of cases. There was a chronic inflammatory reaction of different intensity and extension in 9 specimens (Figure 3). Neutrophils were observed in only 1 case, extending the infiltrate from the pulp stump to the periodontal ligament.

The Brown and Brenn technique showed Grampositive cocci in 3 specimens. In 2 of these cases, the microorganisms were localized in the interface wall of dentine-filling material and in the apical ramifications of the root canal. In the third case, microorganisms were observed in the same places and also in the apical cementum lacunae (Figure 4).

\section{Sealer 26}

There was a complete biological closure of the apical ramifications, by cementum deposition, in 3 cases (Figure 5). In 4 cases, only part of the apical ramifications exhibited closure, while in 3 other cases no closure was observed. Eosinophilic cementum, with an average thickness of $218 \mu \mathrm{m}$, covered the preexisting apical cementum in 6 specimens. There were no areas of cementum resorption in the other cases. Bone tissue exhibited active areas of resorption in 3 cases.

The periodontal ligament, with an average thickness of $380 \mu \mathrm{m}$, was well organized in half of the specimens (Figure 6). In the others, the organization was partial or absent. In 5 cases, there was a mild to severe chronic inflammatory reaction in the periodontal ligament. Neutrophils were observed in only 2 speci-

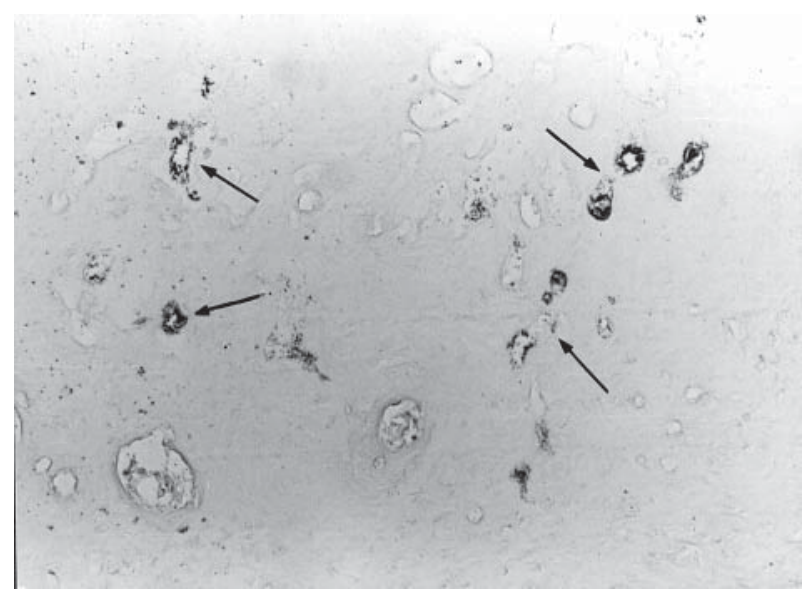

Figure 4. Roth-Lumicon: There were Gram-positive microorganisms (arrows) in the apical cementum lacunae (Brown and Brenn, 200X). 
mens. In half of the specimens, there was no inflammatory reaction.

The Brown and Brenn technique showed Grampositive cocci in 2 specimens. These microorganisms were present in the interface dentin wall-filling material and also in the dentinal tubules and coronary portion of the little canals of the apical delta.

\section{Sealer 26 with a Lumicon Plug}

In 2 cases, the filling material reached the periodontal ligament that exhibited a mild chronic inflammatory reaction with some giant cells. Half of the cases showed pulp stumps with biological closure by neoformed cementum. Biological closure was present in different levels of the pulp stump and also in the periodontal ligament next to the apical foramen.

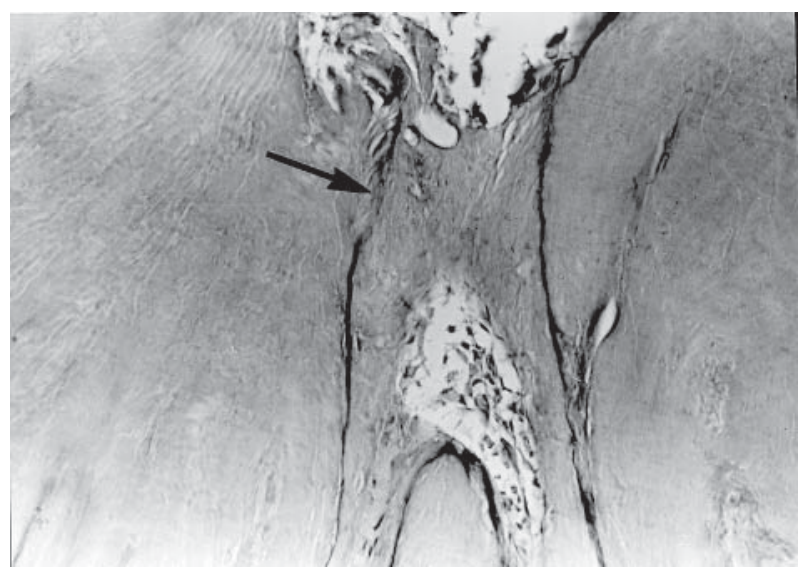

Figure 5. Sealer 26: Observe a complete biological closure by neoformed cementum (arrow) of an apical root canal ramification (H\&E, 200X).

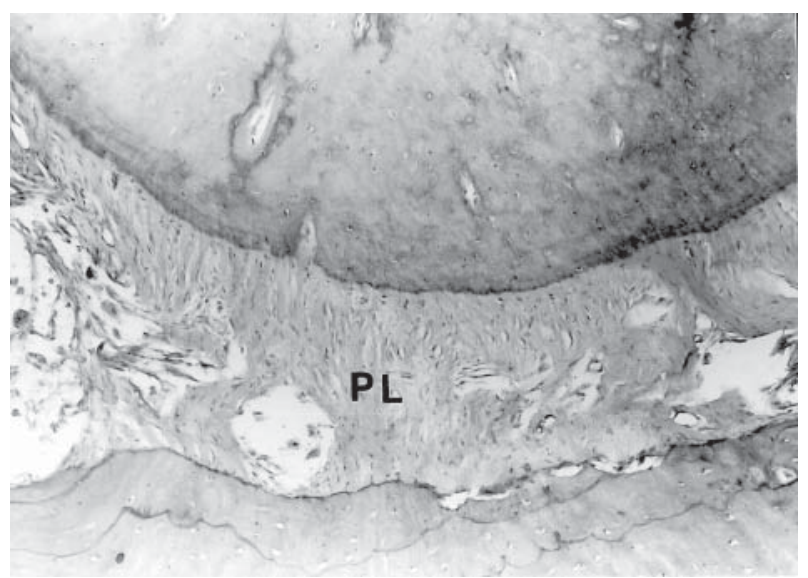

Figure 6. Sealer 26: The periodontal ligament (PL) was well organized and there was no inflammatory reaction (H\&E, 100X).
Eosinophilic neoformed cementum with an average thickness of $23 \mu \mathrm{m}$ was observed in the interior of the apical delta canals in 7 cases, while in the other cases it was observed covering the pre-existing cementum. Resorption areas of bone tissue were observed in only 2 cases.

The periodontal ligament exhibited an average thickness of $373 \mu \mathrm{m}$ and was well organized in 6 cases (Figure 7). The remaining specimens were partially organized. A mild chronic inflammatory reaction was observed in 2 cases.

The Brown and Brenn technique did not show microorganisms in these cases.

\section{Statistical Analysis}

The Kruskal-Wallis test ordered the experimental groups from the best to the worst histomorphological data in the following manner: 1) Sealer 26 with a Lumicon plug, 2) Sealer 26, 3) Roth cement with a Lumicon plug and Roth cement without a plug, thus demonstrating that the groups with Sealer 26 exhibited significantly $(\mathrm{p}=0.01)$ better results than the treatment with Roth cement. The Fisher test showed significantly $(p=0.05)$ less microorganism leakage in root canal fillings that received the protection of a cement plug.

\section{DISCUSSION}

Various factors can explain the better results in root canals treated with Sealer 26 than those treated

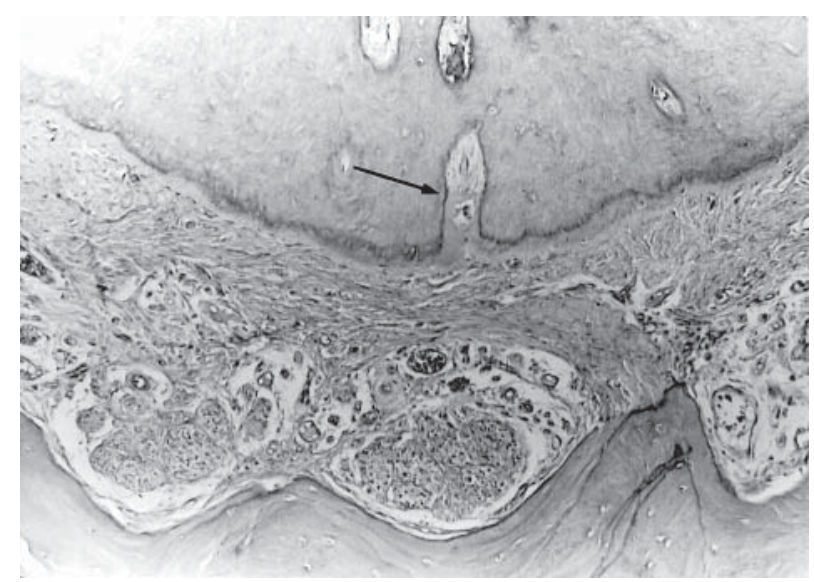

Figure 7. Sealer 26-Lumicon: Note closure by neoformed cementum of an apical ramification (arrow). The periodontal ligament was well organized and free of inflammatory cells (H\&E, 100X). 
with Roth cement: biocompatibility, microorganism leakage, encouragement of apical closure by cementum deposition, etc.

Root canals filled with Sealer 26 exhibited 40\% of cases with complete closure by neoformed cementum while in the remaining cases only part of the small canals of the apical delta were closed. On the other hand, with Roth cement no case with complete closure was observed. The deposition of neoformed cementum after root canal filling with Sealer 26 has been reported in other studies $(6,7)$. The neoformed cementum hinders the contact of the sealer with apical connective tissue, leading to an absent or mild inflammatory reaction. Basically, Sealer 26 contains calcium hydroxide in its formulation and Roth cement contains eugenol. Calcium hydroxide enhances hard tissue deposit $(8,9)$ while eugenol is irritating to connective tissue $(10,11)$, causes tissue destruction (12), bone resorption and severe inflammatory reaction (13). Nevertheless, other experiments did not report biological differences between Roth and calcium hydroxide sealers $(14,15)$.

Another important observation in this experiment was coronal leakage. The Brown and Brenn technique showed $70 \%$ of cases with microorganism leakage with Roth cement, and only $20 \%$ with Sealer 26. When a plug of Lumicon was employed there was $30 \%$ leakage for Roth cement and 0\% for Sealer 26. Obviously, microorganisms and their endotoxin leakage influenced the tissue reactions observed in this study. The microorganism leakage reported in some in vitro research $(1,3,4)$ was confirmed in this in vivo study. Coronal leakage is a reality and must be avoided or better controlled, especially in cases of post space preparation. The use of a plug covering the remaining filling can contribute to avoiding or decreasing microorganism leakage, as was demonstrated in this study. However, an efficient root canal filling using a sealer with good physical and biological properties is also important. We observed in this experiment that the kind of sealer can influence the number of cases with microorganism leakage.

In conclusion, this in vivo experiment demonstrated that microorganism leakage can be observed after root canal filling and post space preparation, if the remaining filling was exposed to the oral environment. The use of a plug of Lumicon was efficient in controlling microorganism coronal leakage, and Sealer 26 was more biocompatible and sealed root canals better than
Roth sealer.

\section{RESUMO}

Foi propósito deste estudo analisar a influência da infiltração marginal coronária no comportamento dos tecidos periapicais de dentes de cães após obturação de canal e preparo para pino. Quarenta canais de dentes de cães foram instrumentados e obturados pela técnica da condensação lateral com cones de guta percha e os cimentos Roth e Sealer 26. Após preparo para pino, o remanescente da obturação foi protegido ou não com um "plug" do cimento temporário Lumicon. Após exposição ao meio oral por 90 dias, os animais foram sacrificados e as peças preparadas para análise histomorfológica. A técnica de Brown e Brenn mostrou $70 \%$ de casos com infiltração de microrganismos para o cimento Roth e $20 \%$ com o Sealer 26. Quando um "plug" de Lumicon foi empregado ocorreu 30\% de casos de infiltração de microrganismos com o cimento Roth e $0,0 \%$ com o cimento Sealer 26. Reação inflamatória crônica foi mais freqüentemente observada com o cimento Roth do que com o Sealer 26. Foi concluído que o "plug" de Lumicon é eficiente no controle da infiltração coronária $(\mathrm{p}=0.05)$ e que o Sealer 26 foi mais biocompatível e selou melhor os canais radiculares do que o cimento Roth $(\mathrm{p}=0.01)$.

\section{REFERENCES}

1. Barrieshi KM, Walton RE, Johnson WT, Drake DR. Coronal leakage of mixed anaerobic bacteria after obturation and post space preparation. Oral Surg Oral Med Oral Pathol 1997;84:310314.

2. Holland R, Cruz A, Souza V, Nery MJ, Bernabé PFE, Otoboni Filho JA, Dezan Junior E. Comportamiento de los tejidos periapicales frente a la exposición de la obturación endodóntica al medio oral. Estudio histológico en dientes de perros. Endodoncia 2000;54:99-108.

3. Gish SP, Walton RE, Wilcox L. Coronal leakage: bacterial penetration through obturated canals following post preparation. J Am Dent Assoc 1994;125:1369-1372.

4. Alves J, Walton R, Drake D. Coronal leakage: endotoxin penetration from mixed bacterial communities through obturated, postprepared root canals. J Endodon 1998;9:587-591.

5. Holland R, Souza V, Otoboni Filho JA, Nery MJ, Bernabé, PFE, Mello W. Técnicas mistas de preparo do canal radicular. Rev Paul Odontol 1991;13:17-23.

6. Sacomani CRR, Holland R, Souza V, Garlippe O. Comportamento dos tecidos periapicais de dentes de cães após obturação de canal com os cimentos Sealer 26 e Sealer 26 modificado. JBE 2001;2:145-152.

7. Leonardo MR, Silva LAB, Utrilla LS, Assed S, Ether SS. Calcium hydroxide root canal sealers - histopathologic evaluation of apical and periapical repair after endodontic treatment. J Endodon 1997;23:428-432.

8. Holland R, Souza V. Ability of a new calcium hydroxide root canal filling material to induce hard tissue formation. J Endodon 1985; 1:535-543.

9. Holland R, Otoboni Filho JA, Souza V, Nery MJ, Bernabé PFE, Dezan Junior E. Calcium hydroxide and corticosteroid-antibiotic association as dressings in cases of biopulpectomy. A compara- 
tive study in dogs' teeth. Braz Dent J 1998;9:67-76.

10. Morse DR, Wilcko JM, Pullon PA, Furst MI, Passo SA. A comparative tissue toxicity evaluation of the liquid components of gutta-percha root canal sealers. J Endodon 1981;7:545-550.

11. Webb Júnior JG, Bussell NE. A comparison of the inflammatory response produced by commercial eugenol and purified eugenol. J Dent Res 1981;60:1724-1728.

12. Torneck CD. Reaction of hamster tissue to drugs used in sterilization of root canal. Oral Surg Oral Med Oral Pathol 1973;35:532540 .
13. Schilder H, Amsterdan M. Inflamatory potential of root canal medicaments. Oral Surg Oral Med Oral Pathol 1959;12:211-221.

14. Molloy D, Goldman M, White RR, Kabani S. Comparative tissue tolerance of a new endodontic sealer. Oral Surg Oral Med Oral Pathol 1992;73:490-493.

15. Economides N, Kotsaki-Kovatsi V, Poulopoulus A, Kolokuris I, Rozos G, Shore R. Experimental study of biocompatibility of four root canal sealers and their influence on the zinc and calcium content of several tissues. J Endodon 1995;21:122-127.

Accepted September 11, 2002 